\title{
Analisis Netralitas Uang Terhadap Siklus Bisnis Riil di Indonesia Periode 2011. M1- 2013. M12
}

\author{
Analysis neutrality of money toward economic growth \\ period of 2011. M1-2013. M12
}

\author{
Achmad Fawaid Hasan, Sebastiana Viphindrartin ${ }^{1}$, Moh. Adenan \\ Jurusan Ilmu Ekonomi, Fakultas Ekonomi, Universitas Jember (UNEJ) \\ Jln. Kalimantan 37, Jember 68121 \\ E-mail:pipin_center@yahoo.com
}

\begin{abstract}
Abstrak
Fenomena terjadinya netralitas uang di berbagai negara mengundang para ekonom untuk mengetahui keberadaannya. Netralitas uang tersebut menjadi perdebatan sepanjang sejarah sampai saat ini dalam ilmu ekonomi. Perdebatan yang terjadi muncul dari dua kubu besar dalam aliran ekonomi yaitu mahzab Klasik dan mahzab Keynes. Adanya temuan netralitas uang oleh kubu Klasik, membawa wacana baru dalam ilmu ekonomi khususnya ekonomi moneter. Namun, aliran Keynes menentang adanya netralitas uang yang juga menjadi wacana baru dalam bidang ekonomi moneter. Tujuan dari penelitian untuk mengetahui keberadaan netralitas uang terhadap pertumbuhan ekonomi di Indonesia, selain itu dari bentuk simulasi model tujuan penelitian ini untuk mengetahui hubungan nilai tukar, inflasi dan suku bunga SBI 1 bulan terhadap pertumbuhan ekonomi di Indonesia. Metode analisis yang digunakan yaitu Ordinary Least Square (OLS) dengan pembentukan simulasi model serta analysis deskriptif naratif. Hasil analysis klausal dengan metode Ordinary Least Square (OLS) pada simulasi model menunjukkan bahwa netralitas uang tidak berlaku di Indonesia, serta sejalan dengan simulasi model suku bunga SBI 1 bulan dan nilai tukar nominal berpengaruh signifikan. Sedangkan inflasi masih menunjukkan hubungan dominan yang sama. Analisi deskriptif naratif memberi gambaran tentang adanya non-netralitas uang di Indonesia, sehingga perlu adanya suatu analisis atau pengawasan terhadap pertumbuhan jumlah uang beredar M2.
\end{abstract}

Kata Kunci: Netralitas Uang, Pertumbuhan Ekonomi.

\section{Abstract}

The phenomenon of the neutrality of money in various countries invited economists determines its existence. Neutrality of money is being debated throughout history until this time in economics. The debate became two mahzab economic is mahzab of Classic and schools of Keynes. The findings of the neutrality of money by the camp Classic, bringing new discourse in economics, especially monetary economics. However, the flow Keynes against the neutrality of money is also a new discourse in the field of monetary economics. The aim of the study to determine the existence of neutrality of money against economic growth in Indonesia, besides of simulation models goal of this study to determine the relationship of exchange rates, inflation and 1-month SBI rate to economic growth in Indonesia. The analysis method used is Ordinary Least Square (OLS) with the establishment of model simulation and analysis of descriptive narrative. Results clause analysis with Ordinary Least Square method (OLS) on model simulations indicate that the neutrality of money is not applicable in Indonesia, as well as simulation models in line with the 1-month SBI interest rate and the nominal exchange rate have a significant effect. While inflation still shows the same dominant relationship. Descriptive narrative analysis gives an overview of the non-neutrality of money in Indonesia, so there needs to be an analysis or monitoring on the growth of the money supply M2.

Keywords: Economic Growth, Neutrality of Money.

\section{Pendahuluan}

Isu keberadaan netralitas uang terhadap variabel ekonomi riil terutama dalam pertumbuhan ekonomi menjadi isu terhangat dalam konteks kebijakan moneter (Arintoko, 2011) [1]. Dampak Kebijakan moneter terhadap variabel riil menjadi isu penting dalam konteks teoritis maupun empiris (Chamley, C. And Polemarchakis H, 1984) [2]. Hal ini yang membuat para ahli ekonomi moneter meninjau ulang keberadaan netralitas uang dalam perekonomian. Apakah uang hanya mempengaruhi variabel nominal tanpa mempengaruihi variabel riil yang biasa disebut dengan money ilusion (Fehr. E., Jean.R. Y. 1999) [3]. Ada tidaknya netralitas uang menjadi isu ekonomi yang layak uji. Pandangan mengenai konsep netralitas uang menurut dikotomi klasik menyatakan bahwa uang tidak mempunyai pengaruh terhadap pertumbuhan ekonomi riil melainkan hanya berpengaruh terhadap peningkatan harga (Utfi, 2011) [4]. Menurut Ahmed. S (1993) [5] netralitas uang adalah peningkatan jumlah uang beredar tidak akan mempengaruhi output riil. Dengan kata lain kebijakan moneter yang dilakukan secara independent oleh bank sentral hanya akan mempengaruhi kenaikan harga, tetapi tidak meningkatkan pertumbuhan ekonomi secara riil (Bullard, 1999) [6].

Berbeda dengan pandangan kelompok keynesian yang menganggap bahwa uang tidak netral terhadap perekonomian. kelompok keynesian menyatakan bahwa pertumbuhan uang beredar akan berdampak pada sedikit aktifitas ekonomi riil dalam jangka pendek, meskipun dalam

1 Corresponding Author 
jangka panjang pertumbuhan uang akan menyebabkan inflasi (Warjiyo, 2004) [7]. Kelompok keynesian menganggap bahwa dalam jangka pendek terjadi kekakuan harga atau upah/ Price rigid atau wage rigid sehingga kurva penawaran agregat tidak berbentuk vertikal (Case dan Fair, 2007) [8]. Ketika ada penambahan jumlah uang beredar yang nantinya akan menggeser kurva permintaan agregat maka dalam jangka pendek masih terdapat penambahan jumlah output riil.

Secara empirik banyak peneliti-peneliti di bidang moneter yang mencari keberadaan netralitas uang terhadap pertumbuhan ekonomi. Study Milton Friedman dan Schwart pada tahun 1963 dalam Wals, (2001) [9] yang melakukan penelitian tentang hubungan antara uang dan silus bisnis di Amerika Serikat dengan menggunakan data selama 100 tahun. Milton Friedman dan Schwart menemukan bahwa perumbuhan uang hanya akan meningkatkan pertumbuhan ekonomi secara nominal dan peningkatan tingkat harga. Hal ini sejalan dengan penelitian King dan Mark, (1997) [10] yang dilakukan diamerika serikat yang menemukan bahwa uang tidak mempunyai pengaruh terhadap output riil dalam jangka panjang. Chen, (2007) [11] juga meneliti netralitas uang dalam jangka panjang di negara korea selatan dan taiwan, yang menemukan bahwa uang netral terhadap output riil.

Selain itu, penelitian Sadeghi dan Seyyed (2013) [12] juga mendukung adanya netralitas uang di negara Iran. Sadhegi dan Seyyed menemukan bahwa jumlah uang beredar M2 tidak berpengaruh terhadap GDP riil dalam jangka pendek dan jangka panjang. Netralitas uang jangka panjang antara uang dan output riil juga ditemukan di negara OECD seperti: Australia, Germany, Netherland dan Amerika sebagaimana penelitian yang dilakukan oleh (Monadjemi dan Huh, tanpa tahun). Adanya netralita uang yang ditemukan dinegara tersebut memberi indikasi bahwa tidak efektifnya kebijakan moneter dalam mrangsang pertumbuhan ekonomi secara riil. Berbeda dengan hasil penelitian Abou, (2014) [13] yang menemukan bahwa netralitas uang tidak berlaku di negara Bahrain, hal ini ditunjukan dari hasil yang signifikan antara jumlah uang beredar M1 dengan GDP riil.

Beberapa isu kritis terkait dengan netralitas uang dari berbagai fakta empiris yang ditemukan diberbagai negara baik negara berkembang maupun negara maju menjadi suatu bidang penelitian yang masih layak uji. Selain itu dari tataran teoritis terdapat perbedaan yang dari kubu klasik dan kubu keynesian tentang netralitas uang. Penelitian ini ingin menguji keberadaan netralitas uang di Indonesia dan ingin mengetahui bagaimana dampak jumlah uang beredar M2 terhadap pertumbuhan ekonomi di Indonesia dalam jangka panjang selain itu peneliti ingin mengetahui bagaimana dampak sertifikat bank indonesia, inflasi, nilai tukar nominal terhadap pertumbuhan ekonomi di Indonesia dalam jangka panjang.

\section{Metode}

Data yang digunakan dalam penelitian ini adalah data sekunder time series mulai tahun 2001.M1 sampai 2013.M12 yang terdiri dari gross domestik produk dengan harga konstan 2000 atau GDP rill berdasarkan lapangan usaha, IHK sebagai indikator inflasi, kusr nominal sebagai proksi pergerakan nilai tukar, SBI sebagai indikator tingkat suku bunga sertifikat Bank Indonesia. Data penelitian ini diperoleh dari badan pusat statistik (BPS) dan Bank Indonesia.

Model yang dibangun dalam penelitian ini mengadopsi model yang gunakan oleh Julaihah dan Insukindro, (2004)[14]. Adapun persamaan simulasi model ekonomi yang dibentuk dalam penelitian ini adalah sebagai berikut:

$$
\text { GDP riil }=\mathrm{f}(\mathrm{IHK}, \mathrm{SBI}, \mathrm{M} 2, \mathrm{ER})
$$

Kemudian ditransformasikan dalam bentuk ekonometrika dengan model Ordinary least square (OLS).

$$
G D P \text { riil }_{t}=\beta_{0}+\beta_{1} I H K_{t}+\beta_{2} S B I_{t}+\beta_{3} M 2_{t}+\beta_{4} E r_{t}
$$

Kemudian model ekonometrika determenistik diatas diturunkan dalam model stokastik. Adapun model stokastik adalah sebagai berikut:

$$
G D P \text { riil }_{t}=b_{0}+b_{1} I H K_{t}+b_{2} S B I_{t}+b_{3} M 2_{t}+b_{4} E R_{t}+e
$$

Keterangan, GDP riil merupakan pertumbuhan ekonomi riil berdasarkan langan usaha yang dihitung berdasarkan harga konstan 2000, IHK merupakan tingkat inflasi atau kenaikan harga barang dan jasa secara keseluruhan, SBI merupakan suku bunga sertifikat Bank Indonesia surat berharga dalam mata uang rupiah yang diterbitkan oleh Bank Indonesia sebagai pengakuan utang berjangka waktu pendek dengan sistem diskonto dengan tenor 1 bulan, M2 merupakan jumlah uang beredar dengan arti luas yang terdiri dari jumlah uang beredar M1, uang kuasi, dan surat berharga, sedangkan ER adalah nilai tukar rupiah terhadap dollar.

Analsis data yang digunakan adalah analsis klausal dengan menggunakan ordinary leasts square (OLS). Metode OLS yang dikenal dengan metode ordinary lears square merupakan motode ekonometrika untuk mencari hubungan jangka panjang. Metode OLS hanya dapat digunakan untuk menjadi hubuungan jangka panjang atau di kenal dengan analsis linier. Metode OLS ini digunakan untuk mencari hubungan variabel GDP riil dengan jumlah uang beredar M2, IHK, nilai tukar dan suku bunga SBI 1 bulan dalam jangka panjang. Selanjutnya dari simulasi model akan dilakukan pengujian asumsi klasik untuk mengetahui model terbebas dari BLUE. Terakhir, untuk mengetahui stabilitas model dilakukan pengujian CUSUM dan CUSUMQ.

\section{Hasil dan Pembahasan}

\section{Hasil Estimasi Ordinary Least Square (OLS)}

Hasil pengujian tingkat signifikansi yang ditunjukkan oleh Tabel 1 pada model I dilakukan dengan uji Probabilitas. Variabel suku bunga SBI tidak berpengaruh signifikan terhadap GDP riil karena nilai probabilitas SBI 0.0519**> dari $\alpha=5 \%$,sedangkan nilai tukar nominal berpengaruh signifikant terhadap GDP riil yang di buktikan dengan nilai probabilitas nilai tukar nominal $0,0000<$ dari $\alpha=5 \%$, dengan nilai koefisien sebesar - 1.956987. Inflasi yang di proksi dengan indeks harga konsumen berpengaruh signifikan terhadap GDP riil yang di buktikan dengan nilai probabilitas IHK $0,0000<$ dari $\alpha 5 \%$, dengan nilai koefisien sebesar 46.17906. Sedangkan variabel M2 berpengaruh secara signifikant terhadap GDP riil yang dibuktikan dengan nilai probabilitas M2 $0,0000<\alpha=5 \%$ dengan besaran koefisien 45.30715 . 
Pengujian pada model II menunjukan bahwa M2 $0,0000<\alpha$ $=5 \%$ yang artinya M2 berpngengaruh secara signifkan terhadap GDP riil dengan koefisien sebesar 40.93290. Variabel nilai tukar nominal berpengaruh secara signifikan terhadap GDP riil yang dibuktikan dengan nilai probabilitas ER $0,0001<\alpha=5 \%$ dengan nilai koefisien - 2.333804 . Sedangkan untuk variabel inflasi yang diproksi dengan IHK tidak berpengaruh signifikan terhadap GDP riil yang di tunjukan dengan nilai probabilitas IHK $0.9477>\alpha=5 \%$ dengan nilai koefisien sebesar 0.030552 .

Hasil estimasi model III variabel jumlah uang beredar M2 berpengaruh signifikant terhadap GDP riil yang ditunjukan dengan nilai probabilitas M2 $0,0000<\alpha=5 \%$ dengan koefisien sebesar 43.75580. Suku bunga sertifikat bank indonesia berpengaruh signifikant terhadap GDP riil yang ditunjukan oleh nilai probabilitas SBI $0,0000<\alpha=5 \%$ dengan koefisien sebesar 604.5319. Sedangkan untuk variabel IHK juga berpengaruh secara signifikant yang ditunjukan oleh nilai probabilitas IHK $0,0000<\alpha=5 \%$ dengan nilai koefisien sebesar -35.19978 .

Tabel 1. Hasil Estimasi Ordinary Leas Square (OLS) Dengan Simulasi Model

\begin{tabular}{|c|c|}
\hline Model & Keterangan \\
\hline Model I & $\begin{aligned} \mathrm{GDP}= & 121640.2+45.30715 \mathrm{M} 2-241.0941 \\
& \mathrm{SBI}^{*}-1.956987 \mathrm{ER}-46.17906 \mathrm{IHK}\end{aligned}$ \\
\hline Model II & $\begin{aligned} \mathrm{GDP}= & 119713.8+40.93290 \mathrm{M} 2-2.333804 \\
& \mathrm{ER}+0.030552 \mathrm{IHK}^{*}\end{aligned}$ \\
\hline Model III & $\begin{aligned} \mathrm{GDP}= & 106983.5+43.75580 \mathrm{M} 2-604.5319 \\
& \mathrm{SBI}-35.19978 \mathrm{IHK}\end{aligned}$ \\
\hline Model IV & $\begin{aligned} \mathrm{GDP}= & 106709.5+46.72411 \mathrm{M} 2-747.1209 \\
& \mathrm{SBI}-0.845879 \mathrm{ER}^{*}\end{aligned}$ \\
\hline Model V & $\begin{aligned} \mathrm{GDP}= & 119742.7+40.93443 \mathrm{M} 2-2.336359 \\
& \mathrm{ER}\end{aligned}$ \\
\hline Model VI & $\begin{aligned} \mathrm{GDP}= & 98482.94+40.40212 \mathrm{M} 2+0.162880 \\
& \mathrm{IHK}^{*}\end{aligned}$ \\
\hline Model VII & $\begin{aligned} \mathrm{GDP}= & 101159.5+45.78058 \mathrm{M} 2-868.6087 \\
& \mathrm{SBI}\end{aligned}$ \\
\hline
\end{tabular}

*) tidak signifikan pada $\alpha=5 \%$

Sumber : Lampiran D, diolah

Hasil estimasi model IV menunjukkan bahwa variabel $\mathrm{M} 2$ dan SBI berpengaruh signifikant terhadap GDP riil yang di tunjukan oleh nilai probabilitas kedua variabel yaitu 0,0000 dan $0,0000<$ á $=5 \%$. Sedangkan variabel yang berpengaruh tidak signifikant ditunjukkan oleh ER dengan nilai probabilitas $0.0614>$ á $=5 \%$. Hasil estimasi model V menunjukkan bahwa variabel yaitu $\mathrm{M} 2_{\mathrm{t}}$ dan ER berpengaruh signifikant terhadap GDP riil yang di tunjukan oleh nilai probabilitas kedua variabel masing-masing yaitu 0,0000 dan $0,0001<\mathrm{a}=5 \%$.

Hasil estimasi model VI menunjukkan bahwa variabel yaitu $\mathrm{M} 2 \mathrm{t}$ berpengaruh signifikant terhadap GDP riil yang di tunjukan oleh nilai probabilit M2 $0,0000<$ á $=5 \%$. Sedangkan variabel yang berpengaruh tidak signifikant adalah IHK yang di tunjukan oleh nilai probabilitas IHK $0.7387>$ á $=5 \%$. Hasil estimasi model VII menunjukkan bahwa kedua variabel yaitu $\mathrm{M} 2_{\mathrm{t}}$ dan $\mathrm{SBI}$ berpengaruh signifikant terhadap GDP riil yang di tunjukan oleh nilai probabilitas kedua variabel masing-masing yaitu 0,0000 dan $0,0000<a ́$ a $=5 \%$.

Tabel 2. Hasil uji asumsi klasik

\begin{tabular}{cccccccc}
\hline $\begin{array}{c}\text { Uji } \\
\text { Diagnosis }\end{array}$ & I & II & III & IV & V & VI & VII \\
\hline $\begin{array}{c}\text { Multikolineri } \\
\text { tas }\end{array}$ & $\mathrm{x}$ & $\mathrm{x}$ & $\mathrm{x}$ & $\mathrm{x}$ & $\mathrm{x}$ & $\mathrm{x}$ & $\mathrm{x}$ \\
\hline Linearitas & $*$ & $*$ & $*$ & $*$ & $*$ & $*$ & $*$ \\
\hline $\begin{array}{c}\text { Heteroskeda } \\
\text { stisitas }\end{array}$ & $*$ & $*$ & $*$ & $*$ & $*$ & $*$ & $*$ \\
\hline Autokorelasi & $*$ & $*$ & $*$ & $*$ & $*$ & $*$ & $*$ \\
\hline Normalitas & $\mathrm{x}$ & $\mathrm{x}$ & $\mathrm{x}$ & $\mathrm{x}$ & $\mathrm{x}$ & $\mathrm{x}$ & $\mathrm{x}$ \\
\hline
\end{tabular}

x ) bebas dari uji asumsi klasik

* ) tidak bebas dari asumsi klasik

Sumber: lampiran C. 7, diolah

\section{Uji Asumsi Klasik}

Pada tabel 2 sesuai dengan kriteria BLUE tidak semua terpenuhi mulai dari model I sampai VII sebagaimana yang ditunjukan oleh ketujuh tabel di atas. Asumsi multikoleneritas dengan menggunakan correlationmatrix pada ketujuh simulasi model terpenuhi dengan nilai koefisien uji kurang dari 0,8. Hasil ini menunjukan bahwa tidak ada masalah yang serius atau tidak ada hubungan antarvariabel independen (penjelas).

Pengujian linieritas melalui uji Ramsey Reset Test pada simulasi model I sampai VII tidak terpenuhi dengan nilai probabiltas likelihood ratio masing masing sebesar 0.0000 lebih kecil dibandingkan dengan $\alpha(\alpha=5 \%=0.05)$. ketidaklinieran ini disebabkan oleh data yang digunakan tidak linier, sehingga butuh suatu pengujian lebih lanjut mengenai pembentukan model dan uji linieritas pada data yang digunakan. Selain itu, data yang berfluktuasi sangat tinggi membuat data juga tidak linier. Pengujian tersebut memberikan kesimpulan bahwa terdapat masalah yang serius terhadap kesalahan pada ketujuh model.

Pengujian heteroskedastisitas dengan menggunakan White test dengan cross term untuk mendeteksi varian setiap disturbance term memiliki nilai yang konstan atau varian yang yang sama. Jika nilai varaian sama maka nilai residual menjadi heterogen yang menyebabkan koefisien-koefisie regresi tidak efisien. Ketujuh model tersebut tidak terlepas dari asumsi heterokedastisitas, hal ini dibuktikan dengan nilai probabilitas Obs*R-squared masing-masing sebesar 0.0000, $0.0000,0.0000,0.0000,0.0429,0.0054$ dan 0.0002lebih kecil dari $\alpha(\alpha=5 \%=0.05)$. hal ini memberi kesimpulan bahwa ketujuh model tersebut mempunyai masalah spesifik heteroskedatisitas.

Pengujian autokorelasi dengan Breusch-Godfrey Serial Correlation LM Testbertujuan untuk mengetahui variabel pengganggu terhadap variabel yang diteliti. Uji autokorelasi pada simulasi ketujuh model memberikan hasil bahwa semua model tidak terbebas dari asumsi autokorelasi. Hal ini 
dibuktikan oleh semua nilai probabilitas Obs*R-squared pada model lebih kecil dari pada nilai $\alpha(\alpha=5 \%=0.05)$. Hasil pengujian ini memberi kesimpulan bahwa terjadi masalah dalam pembentukan model. Masalah yang timbul karena terdapat variabel lain yang sebenarnya mempengaruhi variabel dependent.

Selain itu, uji normalitas bertujuan untuk mengetahui apakah model tersebut berdistribusi normal atau tidak. Hasil pengujian dengan menggunakan Jarque-Bera test menunjukkan bahwa ketujuh simulasi model tersebut berdistribusi normal. Hal ini terbukti dari nilai probabilitas masing-masing ketujuh model 0.129160, 0.127703, $0.073934,0.141292,0.126670,0.290605$, dan 0.058057 lebih besar dari $(\alpha=5 \%=0.05)$. Hal memberi pemahaman bahwa simulasi ketujuh model yang dibangun berdistribusi secara normal.

\section{Hasil Uji Stabilitas}

Terdapat dua hasil pengujian untuk mengetahui stabilisasi dari model yaitu hasil uji CUSUM dan CUSUMQ. Pengujian CUSUM pada simulasi model berdasarkan pada suatu nilai kumulatif dan jumlah residu yang rekrusif. Pengujian CUSUM dapat dikatakan stabil apabila, nilai kumulatif dari jumlah recrusive residual berada dalam garis pita batasan alpha $(\alpha=5 \%=0.05)$. sebaliknya jika nilai parameter dari jumlah recrusive residual berada di luar garis pita batasan alpha $(\alpha=5 \%=0.05)$, maka moedel tersebut tidak stabil.

Hasil pengujian CUSUM pada model I masih stabil sampai tahun 2008 selebihnya model tidak stabil sebagaimana yang terlihat di dalam gambar 4.7 (a) karena nilai estimator tidak melebihi pita merah dengan alpha $(\alpha=5 \%=0.05)$. Begitu pula hasil uji CUSUM pada model III, IV, V danVII menunjukkan hasil yang stabil sampai tahun 2008 selama periode observasi sebagaimana yang terlihat di dalam gambar 4.7 (e), (g), (i) dan (m). Sedangkan pada model II kurang begitu stabil, hal ini terlihat dari nilai parameter yang melwati pita setelah tahun 2009 merah dengan alpha $(\alpha=5 \%=0.05)$ selama periode observasi. Hal ini memberi kesimpulan bahwa hail pengujian CUSUM dari ketuh model tersebut memiliki parameter yang stabil samapai pada kisaran tahun 2008 dan 2009 mulai periode observasi dengan alpha sebesar $(\alpha=5 \%=0.05)$.

Setelah dilakukan pengujian CUSUM pada ketujuh simulasi model penelitian, selanjutnya dilakukan pengujian CUSUMQ. Pengujian CUSUMQ bertujuan untuk melihat ketepatan koefisien regresi yang dihasilkan. Hasil pengujian CUSUMQ terhadap model I menunjukkan bahwa parameter estimasi tidak stabil. Hal ini dibuktikan oleh nilai recrusive residual yang berada di luar garis pita merah dengan alpha ( $\alpha$ $=5 \%=0.05)$, sebagaimana yang ditunjukkan oleh gambar 4.7 (b). hal ini juga senada dengan hasil pengujian CUSUMQ terhadap model II, III, IV, V, VI dan VII yang memiliki nilai parameter estimasi yang tidak stabil. Hal ini dibuktikan dengan nilai recrusive residual yang berada diluar garis merah sebagaiman yang ditunjukkan oleh gambar 4.7 (d), (f), (h), (j), (l), dan (n). Maka dapat ditarik kesimpulan bahwa pengujian CUSUMQ untuk melihat stabilitas menunjukkan hasil yang tidak stabil, namun bukan berarti model yang dibangun tidak stabil, karena pengujian CUSUMQ hanya pelangkap dari uji stabilitas.

\section{Pembahasan}

\section{Implementasi Model}

Hasil estimasi dengan menggunakan ordinary least square (OLS) serta pemilihan model terbaik. Pemilikhan model terbaik dilakukan dengna uji asumsi klasik dan uji stabilitas. Model terbaik yang dihasilkan terdapat pada model I dengan variabel independent jumlah uang beredar M2, suku bunga Sertifikat Bank Indonesia, nilai tukar nominal dan inflasi. Pemilihan model terbaik ini didasarkan pada uji asumsi klasik dan uji stabilitas.

Perbedaan hasil kajian tentang netralitas uang memang sudah menjadi perdebatan para ekonom mulai dari aliran klasik sampai keynesian, baik perbedaan teori maupun fakta empirik yang terjadi. Akan tetapi, mengingat konsistensi dalam hasil penelitian dengan teori dan fakta empirik harus diperhatikan. Maka dapat dibuat tabel keselasan dari hail penelitian yang ditunjukkan oleh tabel 3.

Tabel 3. Konsistensi hasil penelitian dan teori

\begin{tabular}{cll}
\hline Variabel & \multicolumn{1}{c}{ Teori } & $\begin{array}{l}\text { Temuan dalam jangka } \\
\text { panjang }\end{array}$ \\
\hline M2 & $\begin{array}{l}\text { Model neoklasik } \\
\text { menyatakan bahwa uang } \\
\text { bersifat netral terhadap } \\
\text { output riil }\end{array}$ & $\begin{array}{l}\text { Uang bersifat tidak } \\
\text { netral terhadap output } \\
\text { riil. }\end{array}$ \\
\hline *SBI & $\begin{array}{l}\text { Suku bunga SBI } \\
\text { berpengaruh secara } \\
\text { negatif terhadap output } \\
\text { riil }\end{array}$ & $\begin{array}{l}\text { Suku bunga SBI tidak } \\
\text { perpengaruh secara } \\
\text { signifikan terhadap } \\
\text { output riil }\end{array}$ \\
\hline ER & $\begin{array}{l}\text { Model mundell-fleming } \\
\text { menyatakan bahwa nilai } \\
\text { tukar berpebgaruh } \\
\text { negatif terhadap output } \\
\text { riil }\end{array}$ & $\begin{array}{l}\text { Nilai tukar rupiah } \\
\text { berpengaruh secara } \\
\text { negatif terhadap } \\
\text { output riil }\end{array}$ \\
\hline IHK & $\begin{array}{l}\text { Teori kunatitas uang } \\
\text { menyatakan harga } \\
\text { berpengaruh negatif } \\
\text { terhadap output riil }\end{array}$ & $\begin{array}{l}\text { Harga berpengaruh } \\
\text { secara negatif } \\
\text { terhadap output riil }\end{array}$ \\
\hline
\end{tabular}

*) variabel tidak signifikan

Sumber: kerangka konseptual dan lampiran D 1, diolah

Hasil penelitian ini berdasarkan model memberikan gambaran bahwa tidak semua variabel independent selaras dengan dengan teori dan fakta empiris perekonomian yang ada. Hal ini terlihat dari variabel inflasi yang diproksi dengan IHK berbanding terbalik dengan teori dan fakta empirik yang ada. secara teori seharusnya inflasi berbanding posisitf dengan pertumbuhan ekonomi, akan tetapi temuan dalam penelitian ini berbanding terbalik dengan pertumbuhan ekonomi yang diproksi dengna GDP riil. sedangkan variabel yang lain konsisten dengan teori yang ada mulai dari jumlah uang beredar M2, suku bunga SBI dan nilai tukar nominal.

Variabel yang tidak signifikant hanya suku bunga SBI. Hasil ini memberi sinyal pertama tentang adanaya indikasi tentang adanya non netralitas uang. Logikanya ketika siklus kegiatan ekonomi tidak dipengaruhi oleh suku bunga SBI berarti kebijkan jumlah uang beredar M2 dapat mempengaruhi siklus kegiatan ekonomi, hal ini dicerminkan oleh perilaku perbankan yang menggelontorkan kredit tidak dipengaruhi 
oleh suku bunga SBI, jadi jumlah uang beredar yang digelontorkan ke perbankan tidak kembali lagi ke Bank Indonesia, perbankan lebih memilih untuk menyebar kredit dari pada disimpan dalam bentuk Sertifikat Bank Indonesia.

Indikasi lebih mendalam adanya keberadaan non - netralitas uang di buktikan dengan analsis dengan OLS yang menunjukkan hasil yang signifkant antara jumlah uang beredar M2 yang dominan terhadap pertumbuhan ekonomi. Variabel dominan dapat diketahi dari seberapa konsisten variabel independent tersebut berpengaruh terhadap variabel dependent dalam hal ini pertumbuhan ekonomi yang diproksi dengan GDP riil. Jika variabel independen tersebut berpengaruh konsisten maka dapat dikatakan dominan dan sebaliknya. Variabel dapat diketahui dari proses tabulasi yang ditunjukan oleh Tabel 4 Hasil temuan variabel dominan dari simulasi model.

Tabel 4. Hasil temuan variabel dominan dari simulasi model

\begin{tabular}{ccccc}
\hline Model & M2 & SBi & ER & IHK \\
\hline Model I & Signifikan & $\begin{array}{c}\text { Tidak } \\
\text { signifikan }\end{array}$ & Signifikan & Signifikan \\
\hline Model II & Signifikan & $\mathrm{x}$ & Signifikan & $\begin{array}{c}\text { Tidak } \\
\text { signifikan }\end{array}$ \\
\hline Model III & Signifikan & Signifikan & $\begin{array}{c}\text { Tidak } \\
\text { signifikan }\end{array}$ & Signifikan \\
\hline Model IV & Signifikan & Signifikan & $\mathrm{x}$ & $\mathrm{x}$ \\
\hline Model V & Signifikan & $\mathrm{x}$ & Signifikan & $\mathrm{x}$ \\
\hline Model VI & Signifikan & $\mathrm{x}$ & $\mathrm{x}$ & $\begin{array}{c}\text { Tidak } \\
\text { signifikan }\end{array}$ \\
\hline
\end{tabular}

Model VII Signifikan Signifikan

$\mathrm{x})$ variabel independen tidak dimasukkan dalam model Sumber: Hasil uji dan lampiran D1-D7, diolah

Tabel 4 menjelaskan tentang variabel yang dominan dari simulasi model yang telah diji. Point penting yang menjadi tujuan utama dalam penelitian ini adalah mencari keberadaan netralitas uang di negara Indonesia. Hipotesis tentang adanya netralitas uang sebagaimana yang dikemukakan oleh kaum klasik tidak berlaku di negara Indonesia. Hal ini ditunjukkan oleh hasil uji dari simulasi model yang dibangun berdasarkan penelitian sebelumnya Julaihah dan Insukindro. Adanya bukti jumlah uang beredar M2 yang berpengaruh signifikant terhadap GDP riil mulai dari model 1 sampai 7 menunjukkkan bahwa netralitas uang tidak berlaku di Indonesia. Selama periode percobaan mulai dari model 1 sampai 7 variabel jumlah uiang beredar M2 memiliki sifat yang dominan, hal ini memperkuat adanya keberadaan non netralitas uang di Indonesia.

Kebijakan yang diterapkan oleh Bank Indonesia dengan instrumen jumlah uang beredar M2 masih bisa dilakukan untuk merangsang pertumbuhan ekonomi secara riil. akan tetapi Bank Indonesia harus hati-hati dalam menetapkan besaran jumlah uang beredar M2 dengan memperhatikan sepanjang pergerakannya. Hal ini dikawatirkan akan menimbulkan goncangan pada tekanan harga. Dalam hal teknis pergerakan M2, mungkin Bank Indonesia tidak bisa secara langsung mengontrol M2, mengingat bahwa struktur jumlah uang beredar M2 selain M0 juga terdiri dari M1 dan quasi money. Bank Indonesia tidak bisa secara langsung mengontrol pergerakan Jumlah uang beredar M1 yang terdiri dari uang kartal dan uang giral. Kemungkinan Bank Indonesia hanya bisa mengontrol uang kartal secara langsung, selebihnya untuk uang giral, Bank Indonesia tidak bisa mengontrol secara langsung. Sedangkan untuk quasi money bank Indonesia juga tidak bisa mengontrol secara langsung, hal ini mengingat bahwa struktru dari quasi money terdiri dari jumlah uang yang berada pada rekening giro berjangka, bursa efek dan serta dalam bentuk tabungan.

Selanjutnya, variabel suku bunga SBI masih layak digunakan sebagai instrumen jalur kebijakan untuk mempengaruhi GDP riil. Hal ini, dilihat dari suku bunga yang masih dominan berpengaruh signifikant terhadap GDP riil. Meskipun dalam model I suku bunga SBI tidak signifikant, namun hasil simulasi model selanjutnya suku bunga SBI berpengaruh signifikant berturut-turut. Hal ini menunjukkan bahwa variabel suku bunga SBI masih dominant berpengaruh signifikant. Bank indonesia dapat menggunakan jalur suku bunga SBI dalam mempengaruhi GDP riil. ketika suku bunga SBI dinaikkan maka, output riil akan turun. Logika ini dibangun ketika suku bunga SBI naik maka perilaku perbankan masih lebih suka menyimpan dananya dalam bentuk SBI dari pada menyalurkan dalam bentuk kredit, sehingga akan berpengaruh pada penurunan output riil.

Selain itu variabel lain yang mempengaruhi output riil berdasarkan simulasi model masih dalam koridor dominan. Nilai tukar nominal masih dalam koridor variabel dominan yang berpengaruh signifikant terhadap output riil. hal ini terlihat dari tabel 4 yang menunjukkan nilai tukar nominal berpengaruh signifikant terhadap pergerakan output riil. Meskipun dalam model IV nilai tukar nominal tidak berpengaruh secara signifikant, namun dalam simulasi model yang lain nilai tuakr nominal berpengaruh secara signifikan terhadap output riil. sedangkan inflasi yang diproksi dengan IHK, menunjukkan setengah dominan karena hasil signifikansinya menunjukkan hal yang sama dari simulasi model yang dibentuk. Secara khusus variabel inflasi ini masih perlu dipertimbangkan dan dianalsis lebih lanjut, terkait dengan signifikansinya terhadap output riil.

\section{Simpulan}

Netralitas uang di Indonesia tidak berlaku dalam jangka panjang, kondisi ini menjadi konsikuensi efektifnya kebijakan moneter dalam mempengaruhi pertumbuhan pertumbuhan ekonomi yang diproksi dengan GDP riil; Jumlah uang beredar M2 dominan berpengaruh secara signifikant terhadap siklus bisns riil dalam jangka panjang; Suku bunga SBI, nilai tukar berpengaruh signifikant terhadap pertumbuhan ekonomi, meskipun dalam model I suku bunga SBI tidak signifikant dan pada model IV nilai tukar nomianl tidak signifikant dalam jangka panjang.

Instrumen jumlah uang beredar M2 yang digunakan oleh otoritas moneter dalam hal ini adalah Bank Indonesia untuk merangsang pertumbuhan pertumbuhan ekonomi yang diproksi dengan GDP riil masih efektif dalam jangka panjang. Hal ini terlihat dari hasil uji simulasi model yang berpengaruh dominan terhadap output riil; Fluktuasijumlah uang beredar M2 dalam arti luas harus dianalisis sesuai dengan kebutuhan ekonomi agar tidak berdampak pada 
tekanan inflasi; Suku bunga SBI masih dapat digunakan sebagai instrumen kebijakan untuk merangsang pertumbuhan output riil, mengingat bahwa suku bunga SBI masih berpengaruh dominan terhadap output riil meskipun dalam model I tidak signifikant, namun dalam simulasi model yang lain suku bunga SBI masih signifikant; Instansi yang terkait juga harus memperhatikan pergerakan nilai tukar rupiah, karena nilai tukar rupiah berpengaruh dominan terhadap output riil, meskipun model IV tidak signifikant, namun dalam simulasi model yang lain nilai rupiah berpengaruh signifikant.

\section{Referensi}

Abou, M.S. 2014. Testing The Relationship Between Money Supply And Gdp In Bahrain. International Journal of Economics, Commerce and Management. Vol. II, Issue 5, 2014. ISSN 23480386

Ahmed. S. 1993. Does money affect output ?. Bussines review. Federal reserve bank of philadelphia

Arintoko. 2011. Pengujian netralitas uang dan inflasi jangka panjang di Indonesia. Buletin Ekonomi Moneter dan Perbankan, Juli 2011

Bullard, J. 1999. Testing LongRun Monetary Neutrality Propositions: Lessons from the Recent Research. Federal reserve bank ofst. Louis

Case dan fair. 2007. Prinsip-prinsip ekonomi. jakarta: erlanggga. Jld.2 ED.8
Chamley, C. And Polemarchakis. H.1984. Assets, general equilibrium and the neurality of money. Review of economic studies (1984) LI, 129-138

Chen.S. W. 2007. Evidence of the Long-Run Neutrality of Money: The Case of South Korea and Taiwan. Economics Bulletin,Vol. 3, No. 64 pp. 118.

Fehr. E., Jean.R. Y. 1999. Does Money Illusion Matter? An Experimental Approach. Working Paper Series. No.12. ISSN 1424-0459

Julaihah, umi., dan Insukindro.2004. analsis dampak kebijakan moneter terhadap variabel makroekonomi diIndonesia tahun 1983.1 - 2003.2. Buletin ekonomi moneter dan perbankan, september. Bank Indonesia.

King, Robert G. Dan Mark.W. W. 1997. Testing Long-Run Neutrality. Federal Reserve Bank of RichmondEconomic QuarterlyVolume 83/3 Summer 1997

Sadeghi, M dan Seyyed Y. A. 2013. Modeling the impact of money on GDP and inflation in Iran: Vector-error-correction-model (VECM) approach. African Journal of Business Management. Vol. 7(35), pp. 3423-3434, 21 September, 2013

Utfi, aini. 2011. Studi Netralitas Uang Terhadap Siklus Bisnis Di Indonesia Tahun 1998.I-2010.III: Pendekatan Model Dinamis. Skripsi. Tidak dipublikasikan. Universitas Jember

Wals. C. E. 2001. Menetary theory and policy. Massachusetts institute of technology. ISBN. 0-262-23199-9

Warjiyo. P. 2004. Bank Indonesia: bank sentral republik indonesia. Sebuah pengantar. Jakarta: pusat pendidikan dan study kebanksentralan (PPSK)- Bank Indonesia 